\title{
Mengkaji Penerapan E-Learning pada Anak Usia Dini
}

\author{
Yuanita Kristiani Wahyu Widiastuti ${ }^{\circledR}$, Upik Elok Endang Rasmani², Siti Wahyuningsih ${ }^{3}$ \\ Pendidikan Guru Pendidikan Anak Usia Dini, Universitas Sebelas Maret \\ DOI: $10.31004 /$ obsesi.v5i2.752
}

\begin{abstract}
Abstrak
Tujuan penelitian ini adalah untuk mengidentifikasi e-learning pada jenjang pendidikan anak usia dini. Metode penelitian dengan pengumpulan data melalui wawancara dan pengisian GForm, melibatkan responden terdiri guru dan orang tua peserta didik di sebuah lembaga PAUD di Kota Surakarta. Hasil dari penelitian ini awalnya didapati beberapa kendala antara lain kemampuan paedagogi guru, penguasaan teknologi, serta kemampuan ekonomi. Namun karena saat ini banyak penawaran tutorial maupun belajar instan di berbagai media, bisa dilakukan secara gratis dan berbayar maka Implementasi e-learning pada anak usia dini sudah memberikan pencapaian awal yang baik dimana meskipun dalam kondisi pandemic Covid-19, siswa tetap dapat belajar bersama antara lain melalui virtual classroom yang tentu saja masih diperlukan pendampingan dengan orang tua. Kesimpulannya Guru perlu belajar lebih banyak lagi melalui pelatihan mengajar efektif, efisien dan menyenangkan melalui elektronik seperti webinar yang banyak disediakan oleh pemerintah maupun lembaga pendidikan swasta lainnya.
\end{abstract}

Kata Kunci: e-learning; penerapan; anak usia dini

\begin{abstract}
The purpose of this study is to identify e-learning at the early childhood education level. The research method used was data collection through interviews and filling in the G-Form, involving respondents consisting of teachers and parents of students at an early childhood education institution in the city of Surakarta. The results of this study initially found several obstacles, including the pedagogical ability of teachers, mastery of technology, and economic capacity. However, because currently there are many offers for tutorials and instant learning in various media, which can be done for free and paid, the implementation of e-learning in early childhood has provided a good initial achievement, even though in the conditions of the Covid-19 pandemic, students can still learn together between through virtual classroom, of course, assistance with parents is still needed. In conclusion, teachers need to learn more through effective, efficient and fun teaching training through electronics such as webinars that are widely provided by the government and other private educational institutions.
\end{abstract}

Keywords: e-learning; application; early childhood

Copyright (c) 2020 Yuanita Kristiani Wahyu Widiastuti, Upik Elok Endang Rasmani, Siti Wahyuningsih $\triangle$ Corresponding author:

Email Address : yuanita27@student.uns.ac.id (Jalan Slamet Riyadi No 449, Pajang, Surakarta)

Received 8 September 2020, Accepted 25 October 2020, Published 4 November 2020 


\section{PENDAHULUAN}

Pembelajaran e-learning merupakan suatu bentuk model pembelajaran dengan memanfaatkan teknologi, web dan internet. Pembelajaran ini pertama kali diperkenalkan oleh Universitas Illionis melalui sistem pembelajaran berbasis komputer (Ahmad Johari, 2015). Melalui fasilitas e-learning, siswa dapat belajar kapan dan dimana saja tanpa terbatas oleh jarak, ruang dan waktu. Materi pembelajaran yang disajikan juga lebih bervariasi dimana memuat bentuk visual, audio dan gerak (Ali, 2020). Pembelajaran e-learning merupakan suatu sistem yang diharapkan bukan sekedar menggantikan metode atau materi pembelajaran secara konvensional tetapi juga dapat menambah inovasi metode dan strategi baru dalam proses pembelajaran masa kini. Penerapan e-learning adalah suatu media baru yang dapat mengatasi sikap pasif mahasiswa, menambah gairah belajar, memungkinkan berinteraksi langsung dan memungkinkan mahasiswa belajar secara mandiri.(Nana \& Surahman, 2019)

Pembelajaran e-learning merupakan pembelajaran yang mengeliminasi jarak dan waktu dengan bantuan platform digital berbasis internet sehingga mendukung proses pembelajaran dilakukan tanpa adanya interaksi secara fisik (file:///Users/enjangperairawan/Downloads/ishii2019.pdf, 2020). Model pembelajaran ini dirasa sangat cocok dilaksanakan di masa pandemi Covid-19 karena dapat dilakukan tanpa harus bertatap muka secara langsung dan hanya melalui media virtual classroom seperti zoom, google meet, skype, dan lain sebagainya. Selain platform dan situs edukasi yang telah tersedia, pemanfaatan siaran televisi edukasi juga diperlukan sebagai penunjang (Zhou et al., 2020). Adapun stasiun televisi di Indonesia yang turut menyiarkan siaran-siaran edukasi yaitu TVRI (Televisi Republik Indonesia). Stasiun TVRI ini menyiarkan konten edukasi secara terjadwal sesuai dengan kurikulum yang berlaku.

Di sisi lain pembelajaran berbasis e-learning terkadang membuat siswa merasa bosan, karena hal yang ditampilkan hanyalah hal-hal yang sama setiap harinya yaitu guru memberikan materi melalui media pembelajaran yang telah di sepakati dan siswa mengumpulkan tugas yang diberikan oleh guru kepada siswa. Kurangnya penguasaan teknologi yang di alami oleh guru juga menyebabkan anak cepat bosan dan merasa malas dalam mengikuti pembelajaran berbasis e-learning khususnya pada jenjang pendidikan anak usia dini (Setyorini, 2020). Berdasarkan ilustrasi di atas maka penulis tertarik untuk memberikan solusi pada permasalahan e-learning ini yang mana selama ini pembelajaran pada anak usia dini belum ada pedoman yang jelas. Pedoman yang di tawarkan selama ini masih simpang siur dan menuruti kemampuan orang dewasa di sekelilingnya.

Pendidikan anak usia dini adalah pendidikan yang masih membutuhkan bimbingan orang tua atau orang-orang dewasa di sekitarnya. Demikian juga sebagaimana filosofi bagi anak usia dini akan bermain sambil belajar dan belajar sambil bermain. Oleh karena itu perlu adanya formulasi dalam belajar khususnya pembelajaran berbasis e-learning di masa pandemic covid-19. Google Classroom selama ini menjadi pilihan yang menarik bagi pengguna virtual khususnya untuk menyelesaikan permasalahan pembelajaran e-learning. Tetapi google classroom bersifat monoton dan hanya menampilkan tulisan-tulisan maupun artikel karena kebanyakan penggunanya adalah kalangan pelajar dengan usia menengah ke atas. Namun disini penulis ingin menjadikan google classroom sebagai media pembelajaran berbasis e-learning yang menarik bagi anak usia dini sesuai dengan usia perkembangannya.

Pendidikan Anak Usia Dini merupakan salah satu jenjang pendidikan yang mengimplementasikan metode pembelajaran e-learning selama masa pandemi Covid-19. Dalam penelitian ini didapati bahwa dalam pelaksanaan implementasi pembelajaran $e$ learning masih didapati kendala yang cukup berarti beberapa kendala antara lain kemampuan paedagogi guru, penguasaan teknologi, serta kemampuan ekonomi. Guru menjadi faktor penentu dan faktor utama dalam melaksanakan pembelajaran secara online, mereka harus melek teknologi khususnya teknologi digital dalam melaksanakan pembelajaran ini (Nurkolis \& Muhdi, 2021). Namun kenyataan di lapangan ditemui bahwa guru masih meraba-raba 
dalam melaksanakan pembelajaran online ini, hal ini disebabkan mereka belum pernah menggunakan dan menerapkan model pembelajaran e-learning sebelumnya (UNICEF, 2020).

Guru juga terkadang masih bingung dalam memberikan tugas kepada anak, agar anak tidak mengalami kesulitan dalam mengerjakan tugas yang diberikan oleh guru melalui $e$ learning (Owusu-Fordjour et al., 2020). Langkah sederhana yang dilakukan guru untuk melakukan pembelajaran e-learning adalah dengan memberikan tugas dan link video melalui grup Whatsapp Kelas, yang kemudian ketika selesai mengerjakan maka anak mengupload hasil pekerjaannya melalui grup tersebut dan guru memberikan umpan balik kepada anak. Selain itu dampak belajar di rumah membuat orang tua juga memiliki beban lebih karena juga harus menggantikan guru dalam mengajar di rumah dan selalu memantau setiap tugas belajar anak.

Begitu juga kemampuan siswa PAUD belum maksimal dalam memahami informasi yang komplek, pemecahan masalah, pemakaian alat, (Astini, 2020) dan pelaksanaan kegiatan pembelajaran sehingga perlu adanya dukungan orang tua dan guru khususnya pada masa pandemi saat ini. Pada dasarnya implementasi e-learning pada jenjang pendidikan anak usia dini sudah dapat terlaksana dengan baik, namun yang terutama guru perlu banyak meningkatkan skill yang dimiliki khususnya dibidang teknologi dengan mengikuti pelatihan melalui webinar yang disediakan pemerintah, bertukar pengalaman dengan guru yang lain, melihat tutorial di youtube serta melihat referensi pada sumber pembelajaran online maupun sosial media.

Pembelajaran daring memiliki beberapa dampak positif. Beberapa diantaranya adalah memberikan kemajuan bagi pendidikan di Indonesia karena $75 \%$ siswa melaksanakan pembelajaran daring secara bersamaan selama pandemi COVID-19 (Zaharah \& Kirilova, 2020). Guru pun menjadi semakin inovatif dalam mengemas bahan ajar dan semakin kreatif mengembangkan metode pembelajaran untuk menarik antusiasme siswa (Viner et al., 2020). Model penelitian ini juga dilakukan oleh beberapa peneliti kaitannya dengan penggunaan teknologi informasi dan media digital dalam pembelajaran anak usia dini (Utamingsih, \& Zuliana, 2019; Putri \& Purwanto, 2020; Setyorini, 2020)

\section{METODOLOGI}

Penelitian ini dilaksanakan dengan menggunakan metode kualitatif deskriptif, dilakukan dengan maksud mendeskripsikan permasalahan yang terdapat di dalam lembaga secara rinci terkait pelaksanaan pembelajaran e-learning. Penelitian ini dilaksanakan di TK Warga kota Surakarta. Kriteria kajian yang diteliti berupa: kemampuan paedagogi guru, penguasaan teknologi, serta kemampuan ekonomi. Teknik pengumpulan data dilakukan dengan cara observasi dan wawancara terstruktur. Wawancara terstruktur dilakukan secara daring menggunakan Google Form dengan mempertimbangkan waktu, tempat dan biaya tanpa mengurangi substansi data. Instrumen kajian penerapan e-learning juga di aplikasikan di dalam Google Form. Narasumber terdiri dari kepala sekolah (KS) $(n=1)$, guru kelas B (GKB) $(n=2)$, guru kelas $A(G K A)(n=2)$.

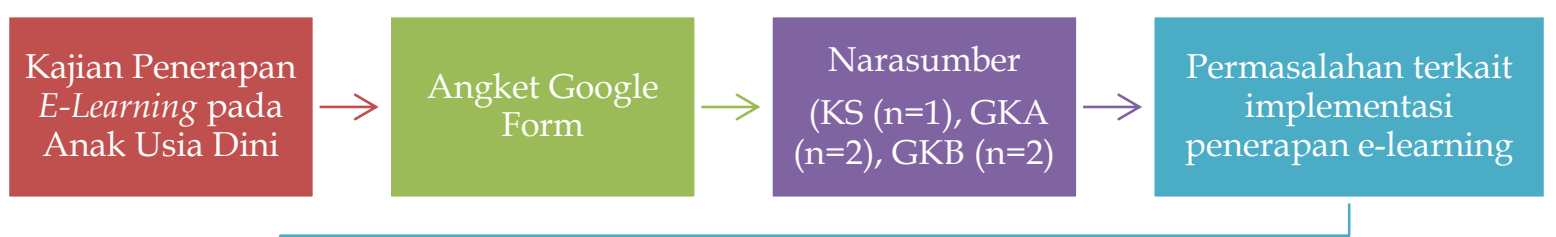

Solusi yang ditawarkan terkait

permasalahan yang dialami

yaitu penerapan e-learning

Gambar 1. Bagan Desain Penelitian 
Analisis data dilaksanakan secara interaktif serta difokuskan pada pelaksanaan kajian terkait penerapan e-learning pada anak usia dini yang dituturkan oleh narasumber, yang kemudian pada tahap berikutnya menarik kesimpulan terkait pelaksanaan pembelajaran elearning pada jenjang pendidikan anak usia dini. Agar lebih memudahkan dalam memahami desain penelitian maka dapat dicermati bagan pada gambar 1 .

\section{HASIL DAN PENELITIAN}

Pandemi Covid-19 menjadi salah satu permasalahan yang memberikan dampak luar biasa dalam segala aspek kehidupan diseluruh negara di dunia dan tidak terkecuali Indonesia. Sejak 02 Maret 2020 dimana kasus pertama Covid-19 di temukan di Indonesia dan terus berkembang setiap harinya, menjadikan pemerintah melakukan pemutusan kebijakan berupa tindakan tegas pembatasan interaksi sosial besar-besaran (UNICEF, 2020). Hal ini memberikan dampak yang luar biasa dalam segala bidang kehidupan, tidak terkecuali bidang pendidikan. Indonesia telah menutup sekolah disemua jenjang pendidikan sejak awal bulan Maret sehingga sebanyak 60 juta siswa tidak dapat bersekolah dan bertemu secara face to face tetapi beralih ke mode pembelajaran e-learning dan dari jarak jauh diseluruh daerah (UNICEF, 2020).

Pembelajaran e-learning merupakan suatu sistem yang dapat memfasilitasi siswa belajar lebih luas, lebih banyak dan lebih bervariasi, selain itu siswa juga dapat belajar dimana saja dan kapan saja tanpa terbatas oleh jarak, ruang dan waktu (Victoria, 2019). Bahkan materi pembelajaran yang lebih bervariatif tidak hanya dalam bentuk verbal, tetapi lebih bervariasi seperti visual, audio dan gerak. Menurut The Report of the Commission on Technology and Adult Learning (2001) dalam Bonk Curtis J. (2002) defines e-learning as "instructional content or learning experiences delivered or enabled by electronic technology" yang artinya e-learning merupakan suatu konten yang di dalamnya memuat pembelajaran yang ditampilkan melalui alat elektronik. Dibutuhkan tenaga pengajar dan siswa yang berkomunikasi secara interaktif dalam melaksanakan pembelajaran berbasis e-learning.

Pendidikan Anak Usia Dini merupakan salah satu jenjang pendidikan yang menerapkan sistem pembelajaran e-learning dimasa pandemi Covid-19. Implementasi elearning dalam pendidikan anak usia dini dilaksanakan oleh guru dengan memberikan pembelajaran setiap hari melalui Google Classroom, serta dengan melaksanakan video conference setiap beberapa hari sekali untuk memantau perkembangan siswa di rumah masing-masing (Kemendikbud, 2020). Pemerintah dalam hal ini Kemendikbud menghimbau untuk para guru senantiasa memberikan inovasi pembelajaran yang menarik dan senantiasa berinovasi sehingga anak tidak jenuh belajar meskipun melakukan pembelajaran melalui model e-learning.

Pemerintah juga sudah melakukan kerjasama dengan layanan penyedia jasa pendidikan lainnya seperti google classroom, ruang guru, zenius, moodle, zoom, dan lain sebagainya untuk semakin mendukung program implementasi e-learning semasa Covid 19 (CNN Indonesia, 2020). Pemerintah sudah berjuang memberikan fasilitas pembelajaran elearning baik terkait penyedia layanan kuota maupun layanan program e-learning (Lestari \& Gunawan, 2020). Namun, Implementasi e-learning memerlukan tingkat kreativitas yang ditinggi dimana guru menjadi faktor utama, apakah pembelajaran dapat dilakukan secara interaktif dan menyenangkan atau pembelajaran menjadi membosankan.

Pelaksanaan implementasi e-learning khususnya dalam pendidikan anak usia dini selama kurang lebih empat bulan pelaksanaan, kemendikbud mengatakan sudah cukup memberikan dampak yang baik dalam bidang pendidikan. Namun kenyataannya dibalik pernyataan tersebut guru senantiasa dipaksa untuk memutar otak dan juga senantiasa mengupdate dirinya dalam menjalankan implementasi e-learning, baik dalam melaksanakan pembelajaran maupun dalam menyediakan konten pembelajaran yang kreatif dan inovatif khususnya untuk anak usia dini, agar anak tidak mudah bosan dan dapat mengikuti kegiatan pembelajaran dengan penuh semangat (Darmalaksana et al., 2020). Hal ini juga terjadi di salah 
satu PAUD di kota Surakarta, dimana guru setiap harinya harus memeras otak membuat rancangan pembelajaran, mencari referensi pembelajaran yang sesuai dengan tema dan mendesain pembelajaran secara kreatif, inovatif dan menyenangkan.

Implementasi e-learning mengharuskan guru untuk senantiasa memperbaiki diri dan semakin melek teknologi, karena dalam pelaksanaan e-learning penguasaan teknologi menjadi faktor utama keberhasilan pembelajaran tersebut (Lapada et al., 2020). Namun guru banyak merasakan kelelahan baik fisik maupun psikis karena hal yang mereka terapkan adalah hal yang baru dimana sangat bertolak belakang dengan pembelajaran model offline. Mereka mengeluhkan tidak adanya pedoman khusus yang harus dilakukan sehingga dalam pelaksanaannya mereka masih meraba-raba dan belum mengetahui bentuk implementasi elearning yang diharapkan (CNNIndonesia, 2020).

Guru masih belum dapat memaksimalkan penggunaan aplikasi yang disediakan oleh pemerintah seperti aplikasi Halo Bunda, Google Classroom, Zoom, Ruang guru, dan lain sebagainya dengan alasan tidak mengerti cara menggunakannya dan pada akhirnya hanya menggunakan aplikasi Google Classroom sebagai sarana untuk menshare materi serta komunikasi dengan siswa dan youtube sebagai sarana dalam mencari video interaktif terkait pembelajaran hari itu. Selain itu jaringan komunikasi juga menjadi faktor lain yang membuat baik guru, orang tua maupun siswa mengalami kendala dalam melaksanakan implementasi e-learning (Kasih, 2020).

Tantangan lain yang dihadapi oleh siswa, guru dan orang tua dalam pelaksanaan pembelajaran e-learning berupa 1) tantangan yang terkait dengan siswa berupa komunikasi dan sosialisasi yang terbatas di antara siswa, perlunya pendidikan khusus, serta waktu pemahaman pembelajaran lebih lama. 2) tantangan yang terkait dengan orang tua adalah permasalahan manajemen waktu antara pekerjaan dengan pola pembelajaran dan pengasuhan bagi anak, kurangnya keterampilan penguasaan teknologi, serta tagihan internet yang semakin membengkak setiap harinya (Purwanto et al., 2017).

Nadiem Makarim selaku Menteri Pendidikan mengungkapkan bahwa " ini bukan situasi yang ideal tetapi keadaan darurat, dan karena itu saya mengerti tidak semua pembelajaran akan optimal, tetapi mari kita semua belajar dan beradaptasi dengan situasi seperti ini" Ia menekankan bahwa tidak semua pembelajaran e-learning selalu menggunakan internet, terlebih dalam kondisi darurat saat ini (CNNIndonesia, 2020). Pelaksana Tugas (Plt.) Direktur Jenderal Pendidikan Anak Usia Dini, Pendidikan Dasar, dan Menengah Kemendikbud Harris Iskandar berpendapat guru tak mesti terpaku pada pembelajaran daring dan pemberian tugas. Kreativitas menjadi kunci utama dalam pelaksaaan pembelajaran elearning dikala seperti ini.

Work From home dapat dilakukan secara efektif oleh guru, sekolah, oang tua dan siswa jika dilaksanakan dengan tanggung jawab dimana pihak yang bekerja sama saling memberikan kinerja yang terbaik meskipun mereka bekerja ditempat yang berbeda, selain itu kunci utama pelaksanaan e-learning di sekolah adalah komunikasi dua arah antara guru dan orang tua maupun orang tua dengan anak, dan anak dengan guru (Khasanah et al., 2020). Selain itu sumber daya manusia dalam hal ini juga harus di tingkatkan dimana guru juga harus mau untuk mengupdate dirinya untuk memberikan pelayanan yang terbaik bagi orang tua dan siswa.

Lebih lanjut, Direktur Guru dan Tenaga Kependidikan Pendidikan Menengah dan Pendidikan Khusus Kemendikbud, Praptono, menyebut momentum belajar dari rumah ini bisa digunakan untuk mencapai tujuan pengajaran yang lebih kreatif (Anggun, 2020). Hal yang dapat dilakukan oleh guru untuk mengimplementasikan pembelajaran berbasis elearning dengan lebih baik lagi dikala pandemi ini adalah dengan melakukan beberapa cara seperti, 1) bekerjasama dengan orang tua dalam mensukseskan pelaksanaan implementasi elearning dalam pendidikan dengan cara selalu menjalin dan menjaga komunikasi yang baik dengan orang tua, melalui cara bertanya jawab dan mendiskusikan apa yang terbaik untuk siswa termasuk refleksi aktivitas belajar di rumah (Syandri \& Akbar, 2020); 2) menjaga agar 
aktivitas pembelajaran e-learning dapat berlangsung dengan baik dan menyenangkan untuk siswa dengan cara memberikan petunjuk praktis dan beragam ide yang dapat dilakukan oleh siswa dan orang tua saat di rumah (Taufik et al., 2019); 3) menggunakan aplikasi yang telah disediakan pemerintah sebagai sarana dalam mengembangkan implementasi e-learning tanpa harus mengalami kebingungan dalam menyusun materi dan bahan yang akan diberikan kepada siswa ( Murugadoss \& Kishore, 2020); 4) banyak mencari informasi di media sosial dan ilmu dengan mengikuti pelatihan webinar yang disediakan oleh pemerintah maupun lembaga swasta lainya sehingga dapat menambah ilmu dalam melaksanakan pembelajaran elearning selama masa pandemi Covid 19 (Daniel, 2020); 5) melihat video tutorial pembelajaran aktif, kreatif, inovatif dan menyenangkan yang ditampilkan melalui youtube ataupun media sosial lainnya; 6) melakukan share pengalaman dengan guru lain untuk dapat saling bertukar ilmu terkait peningkatan implementasi pembelajaran e-learning dimasa pandemi ini; 7) yang paling utama adalah berani untuk senantiasa mengupdate dirinya dan semangat dalam mencari informasi terbaru dalam pembelajaran e-learning guna meningkatkan skill diri dan berani mencoba hal baru setiap harinya agar tujuan pembelajaran dapat dicapai meskipun melalui e-learning.

Implementasi e-learning dimasa sekarang adalah salah satu peluang dan momentum yang di harapkan oleh pemerintah dalam melaksanakan pendekatan pembelajaran kearah yang diharapkan saat ini yaitu pembelajaran dalam jaringan. Pelaksanaan implementasi e-learning juga didukung oleh pemerintah dengan bukti bahwa pemerintah telah membuat aplikasi pembelajaran dan telah bekerjasama dengan pihak penyedia jasa layanan pendidikan dan provider dalam mensukseskan implementasi e-learning dimasa pandemi Covid-19.

\section{SIMPULAN}

Penerapan e-learning berupa Google Classroom yang berbentuk tampilantampilan tema sesuai dengan usia perkembangan pada anak usia dini, akan membantu keberlangsungan pembelajaran secara menyenangkan. Google Classroom yang bernuansa anak-anak akan sangat menyenangkan dan menarik bagi anak usia dini, karena di dalamnya terdapat tema-tema yang menarik dan aplikasi berupa video pembelajaran yang sesuai dengan perkembangan anak misalnya tema terkait lingkungan, binatang, tanaman, tanah air ku, keluargaku, air udara api, gunung dan alam semesta. Guru dan orang tua akan merasa terbantu dengan adanya google classroom untuk anak usia dini dengan fitur yang dikemas secara menarik dan menyenangkan.

\section{UCAPAN TERIMA KASIH}

Terima kasih kepada subjek penelitian yang telah membantu melaksanakan penelitian ini selama masa pandemic Covid-19 dan kepada rekan saya yang telah membantu dalam penyusunan penelitian hingga jurnal baik moral maupun material.

\section{DAFTAR PUSTAKA}

Ahmad Johari, S. (2015). Konsep Pembelajaran. E-Prints UTM, 8, 1-43. http:/ / repository.usu.ac.id/bitstream/123456789/23790/4/Chapter I.pdf

Ali, W. (2020). Online and Remote Learning in Higher Education Institutes: A Necessity in light of COVID-19 Pandemic. Higher Education Studies, 10(3), 16. https:// doi.org/10.5539/hes.v10n3p16

Anggun, P. (2020, May). Strategi Guru PAUD Mendukung Anak Belajar dari Rumah. 01 May. http://anggunpaud.kemdikbud.go.id/index.php/berita/index/20200501082139/Str ategi-Guru-PAUD-Mendukung-Anak-Belajar-dari-Rumah

Astini, N. K. S. (2020). Pemanfaatan Teknologi Informasi dalam Pembelajaran Tingkat Sekolah 
Dasar pada Masa Pandemi Covid-19. Jurnal Lembaga Penjaminan Mutu STKIP Agama Hindu Amlapura, 11(2), 13-25.

Ayu, P., Lestari, S., \& Gunawan, D. (2020). The Impact of Covid-19 Pandemic on Learning Implementation of Primary and Secondary School Levels. In Indonesian Journal of Elementary and Childhood Education (Vol. 1, Issue 2). https://journal.publicationcenter.com/index.php/ijece/article/view/141

Bonk, C. J. (2002). Online Training in an Online World. In Growth Lakeland.

CNN Indonesia. (2020). Akses Ponsel Terbatas, Nadiem Sebut Guru “Terpaksa” Kreatif. CNN Indonesia. $\quad$ https://www.cnnindonesia.com/nasional/20200324150150-20486501/akses-ponsel-terbatas-nadiem-sebut-guru-terpaksa-kreatif

Daniel, S. J. (2020). Education and the COVID-19 pandemic. Prospects, 49(1-2), 91-96. https:// doi.org/10.1007/s11125-020-09464-3

Darmalaksana, W., Hambali, R. Y. A., Masrur, A., \& Muhlas. (2020). Analisis Pembelajaran Online Masa WFH Pandemic Covid-19 sebagai Tantangan Pemimpin Digital Abad 21. Karya Tulis Ilmiah (KTI) Masa Work From Home (WFH) Covid-19 UIN Sunan Gunung Djati Bandung Tahun 2020, 1(1), 1-12.

file:///Users/enjangperairawan/Downloads/ishii2019.pdf. (2020). Media Komunikasi Digital, Efektif Namun Tidak Efisien,Studi Media Richness Theory Dalam Pembelajaran Jarak Jauh Berbasis Teknologi Di Masa Pandemi. Global Komunika, 1(2), $1-13$.

Fitra. (2020, May). Guru Minta Kemdikbud Benahi Masalah Pembelajaran Jarak Jauh. CNN Indonesia, 1https:// www.liputan6.com/news/read/4259413/6-ribu. https:// www.cnnindonesia.com/nasional/20200509095010-20-501561/guru-mintakemdikbud-benahi-masalah-pembelajaran-jarak-jauh

Kasih, A. P. (2020, April). Anak Mulai Bosan dan Menolak Belajar di Rumah, Orangtua Lakukan Ini.

Kompas.Com. https://edukasi.kompas.com/read/2020/04/14/170654471/anak-mulai-bosan-danmenolak-belajar-di-rumah-orangtua-lakukan-ini.

Kemendikbud. (2020, March). Kemendikbud Bekerja Sama dengan Operator Telekomunikasi Sukseskan Pembelajaran di Rumah. Kementerian Pendidikan Dan Kebudayaan. https://www.kemdikbud.go.id/main/blog/2020/03/kemendikbud-bekerja-samadengan-operator-telekomunikasi-sukseskan-pembelajaran-di-rumah

Khasanah, D. R. A. U., Pramudibyanto, H., \& Widuroyekti, B. (2020). Pendidikan Dalam Masa Pandemi Covid-19. Jurnal Sinestesia, 10(1), 41-48. https:// sinestesia.pustaka.my.id/journal/article/view/44

Lapada, A. A., Miguel, F. F., Robledo, D. A. R., \& Alam, Z. F. (2020). Teachers' Covid-19 Awareness, Distance Learning Education Experiences and Perceptions towards Institutional Readiness and Challenges. International Journal of Learning, Teaching and Educational Research, 19(6), 127-144. https:/ / doi.org/10.26803/ijlter.19.6.8

Nana, N., \& Surahman, E. (2019). Pengembangan Inovasi Pembelajaran Digital Menggunakan Model Blended POE2WE di Era Revolusi Industri 4.0. Prosiding SNFA (Seminar Nasional Fisika Dan Aplikasinya), 4, 82. https:/ / doi.org/10.20961/prosidingsnfa.v4i0.35915

Nurkolis, N., \& Muhdi, M. (2020). Keefektivan Kebijakan E-Learning berbasis Sosial Media pada PAUD di Masa Pandemi Covid-19. Jurnal Obsesi : Jurnal Pendidikan Anak Usia Dini, 5(1), 212. https://doi.org/10.31004/obsesi.v5i1.535

Owusu-Fordjour, C., Koomson, C. K., \& \& Hanson, D. (2020). The impact of COVID-19 on learning-the perspective of the Ghanaian student. European Journal of Education Studies, 7(3), 88-101. https://doi.org/10.5281/zenodo.3753586

Purwanto, A., Pramono, R., Asbari, M., Santoso, P. B., Wijayanti, L. M., Hyun, C. C., \& Putri, R. S. (2017). Studi Eksploratif Dampak Pandemi COVID-19 Terhadap Proses Pembelajaran Online di Sekolah Dasar. EduPsyCouns: Journal of Education, Psychology and Counseling, 2(1), 165-170. 
DOI: 10.31004/obsesi.v5i2.752

Putri, R. S., Purwanto, A., Pramono, R., Asbari, M., Wijayanti, L. M., \& Hyun, C. C. (2020). Impact of the COVID-19 pandemic on online home learning: An explorative study of primary schools in Indonesia. International Journal of Advanced Science and Technology, 29(5), 4809-4818.

Raja Murugadoss, J., \& Krishna Kishore, K. (2020). Effectiveness of E-learning in rural India and significance of self-directed learning. International Journal of Advanced Science and Technology, 29(6), 6015-6020. https://www.scopus.com/inward/record.uri?eid=2s2.0-85085881649\&partnerID=40\&md5=9406fc6559442e6c4158ba546cb59427

Setyorini, I. (2020). Pandemi covid-19 dan online learning: apakah berpengaruh terhadap proses pembelajaran pada kurukulum 13? Journal of Industrial Engineering $\mathcal{E}$ Management Research, 1(1), 95-102. https://doi.org/https://doi.org/10.7777/jiemar.v1i1

Syandri, S., \& Akbar, F. (2020). Impact of Corona Virus Outbreak Towards Teaching and Learning Activities in Indonesia. SALAM: Jurnal Sosial Dan Budaya Syar-I. https://doi.org/10.15408/sjsbs.v7i3.15105

Taufik, A., Apendi, T., Saidi, S., \& Istiarsono, Z. (2019). Parental Perspectives on the Excellence of Computer Learning Media in Early Childhood Education. JPUD - Jurnal Pendidikan Usia Dini, 13(2), 356-370. https:/ / doi.org/10.21009/jpud.132.11

UNICEF. (2020). COVID-19 dan Anak-Anak di Indonesia Agenda Tindakan untuk Mengatasi Tantangan Sosial Ekonomi. Journal of Education, Pshycology and Counseling, 2(April), 112. www.unicef.org

Utaminingsih, S., \& Zuliana, E. (2018). Pandemi covid-19 dan online learning: apakah berpengaruh terhadap proses pembelajaran pada kurukulum 13? Refleksi Edukatika: Jurnal Ilmiah Kependidikan, 9(1), 75-81. https:// doi.org/10.24176/re.v9i1.2811

Victoria, S. G. (2019). Learning from home for early childhood education and care services. https://www.education.vic.gov.au/childhood/professionals/learning/Pages/Learn ing-from-home-in-an-early-childhood-setting.aspx

Viner, R. M., Russell, S. J., Croker, H., Packer, J., Ward, J., Stansfield, C., Mytton, O., Bonell, C., \& Booy, R. (2020). School closure and management practices during coronavirus outbreaks including COVID-19: a rapid systematic review. In The Lancet Child and Adolescent Health (Vol. 4, Issue 5, pp. 397-404). https://doi.org/10.1016/S23524642(20)30095-X

Zaharah, Z., \& Kirilova, G. I. (2020). Impact of Corona Virus Outbreak Towards Teaching and Learning Activities in Indonesia. SALAM: Jurnal Sosial Dan Budaya Syar-I, 7(3). https://doi.org/10.15408/sjsbs.v7i3.15104

Zhou, L., Wu, S., Zhou, M., \& Li, F. (2020). 'School's Out, But Class' On', The Largest Online Education in the World Today: Taking China's Practical Exploration During The COVID-19 Epidemic Prevention and Control As an Example. SSRN Electronic Journal, 4(2), 501-519. https:// doi.org/10.2139/ssrn.3555520 